\title{
LIVONIAN SOCIAL NETWORKS AND LANGUAGE SHIFT
}

\author{
Patrick O'Rourke \\ University of Tartu
}

\begin{abstract}
This article presents a study of Livonian social networks in the beginning of the 20th century during a time of language shift. In this study, I examine whether the Livonian communities were experiencing a language shift irrespective of the population displacements during the two World Wars, which has often been given as the main reason for the Livonian language shift to Latvian. I apply the Network Strength Scale to examine if social network centrality played a role in the language shift. The study focuses on the Livonian villages of Vaid and Sikkrõg and social factors relevant to the mapping of the social network are taken from Edgar Vaalgamaa's survey in 1935-1937. The results indicate that generational differences played a more important role than centrality in the social network in determining Latvian influence.
\end{abstract}

Keywords: historical linguistics, sociolinguistics, social networks, language shift, Livonian language

DOI: https://doi.org/10.12697/jeful.2018.9.2.04

\section{Introduction}

This study focuses on the Livonian language in the first half of the 20th century as a case study of historical social networks of two speech communities during a time of language shift. The study provides a general overview of the sociolinguistic situation among Livonian speakers during a time when the Livonian literary language was actively developed, yet the amount of Livonian speakers was in decline. Despite a steady interest in the study of the Livonian language, the question of language attrition has not received scholarly attention. The explanation for Livonian language attrition has largely been the population displacements of Livonians during the two World Wars (cf. Moseley 2014: 67). However, this might not be the only, or even the main reason for the Livonians shifting to speaking Latvian. The purpose of this study is to analyse Livonian language materials between the years 1920 and 1940 to determine whether Livonian speakers were bilingual in Latvian and to what extent their bilingualism was indicative of language attrition. 
In this study, I aim to answer the following research questions:

How widespread was Livonian-Latvian bilingualism among Livonians in the interwar period?

Were there influences of the Latvian language in the Livonian language? If so, what?

Were there differences of Latvian influence among the Livonian speakers' language? If so, what were they and what social factors could account for the possible differences?

If there was widespread Livonian-Latvian bilingualism during the period of study, then this would have a profound effect on the structure of Livonian. Since I expect widespread bilingualism (see section 2 for the social context of Livonians), my first research hypothesis is that the Livonian speech community was in the process of language shift to Latvian already during the interwar period and that the language shift can be seen in the structure of the contemporary Livonian language.

The mapping of social networks provides a quantitative comparison with the qualitative differences of the Livonian language of the speakers by connecting linguistic features with specific speakers. This would enable studying the development of the Livonian language through the speakers' relationship with one another. My second research hypothesis is that speakers more central in Livonian social networks have less Latvian influence in their language. This hypothesis largely follows the conclusions in literature on network roles (cf. Bergs 2005: 39-42). If the hypothesis is correct, then the answer to my second and third research questions is that there were different degrees of Latvian influence among the Livonian speakers and that this can be explained by their degree of centrality within the communities.

This study focuses on the social context of a historical community. Therefore, it can be categorised within the field of historical sociolinguistics. To my knowledge, such an approach has not been used in studying the Livonian language. This is also that case with the model of social network analysis (SNA) in studying the Livonian language community, although the model has been used in studying, for example, Vorro villages (Mets 2010). As such, the general nature of this study can be regarded as preliminary.

I will describe the context of the interwar Livonian speech community in section 2. I will comment on the theoretical background of my study, that is, social network analysis, in section 3. In section 4, 
I will describe the materials and method of my study. I will present the procedure and results of my analysis in section 5 . In section 6 , I will conclude the article.

\section{Interwar Livonian speech community}

Up to the mid-20th century, the Livonian people practised mainly sea fishing and the Livonian speech community was already small by the time ethnographic studies were made among them: at the beginning of the 20th century there were less than 2000 Livonians (The Red Book 1993: Livonians). The Livonians lived in large households, with up to four different families sharing living quarters (Viitso, p.c.).

Despite the relatively small communities and uniform subsistence economy, there were three dialect areas: West Livonian (spoken in Lūž and Pizā (Latvian: Miķeļtornis), Central Livonian (spoken in Īra (Latvian: Lielirbe)) and East Livonian (spoken east of İra), Central Livonian having the characteristics of a contact dialect (Viitso 2008: 225-232). This would indicate that the three speech communities were stable and tight-knit, as greater similarity would indicate that the communities were either recent or more interconnected.

The Livonian language has had unfavourable conditions for its survival since the German conquest in the late 12th century. From the 13th century onwards, German became the language of official use. This led to the Germanisation of the ruling class as well as raised the prestige of the German language. Even during the creation of vernacular literature in the form of Protestant liturgies in the 16th century, Livonian literature was practically non-existent, as the numerically fewer Livonians were grouped together with either Estonians (when in contrast to Latvians) or with Latvians (when describing linguistic competence). Livonians were reported to be fluent in Latvian, therefore, for example, church services were conducted in Latvian (Vunk 2014: 44-47).

The Livonians experienced a dramatic change in stability during the First World War, when the entire Courland coast, homeland of the 20th century Livonians, was evacuated. During this time, the Livonians lived scattered either in Latvian communities or abroad in Estonia, Finland, or Russia. This resulted in the traditional communities breaking up, leading to increased Latvianisation of the Livonians (Blumberga 2011: 136). (However, this affected especially Livonians living in Latvia during the diaspora, whereas Livonians living abroad had a greater tendency to 
preserve the Livonian language (Viitso, p.c.). A similar condition to this tendency was the general proximity of Saaremaa to the Courland coast, since the Estonian community of Saaremaa might have acted as a linguistic reserve for the Livonians whose language was similar to the Estonian language, preventing Livonians from assimilating to the Latvian community (Grünthal 2011: 201-202).)

Livonians were heavily influenced by the Latvian-speaking majority. The influence had begun already in the mid-20th century, when Livonian fishermen under Dundaga manor resisted the local baron's raise of rent in 1859. As a result, 38 out of 77 tenants were evicted from their homes, after which the baron replaced them with Latvian tenants (Blumberga 2011: 128). This resulted in the increase of Latvian-speaking people among the Livonians. Also, mixed marriages between Livonians and Latvians became more common, resulting in Latvian being the domestic language in more and more families. During the 1930s, around onefourth of Livonians used the Livonian language (ibid.: 137).

Livonians regarded the Latvian language as the language of school, church and communication with the outside world, which is why even fully Livonian parents often spoke Latvian to their children. The older generation in the interwar period had a stronger ethnic consciousness (ibid.: 130). However, even in a fully Livonian context the Latvian language had a high prestige, an example being folk songs. Latvian folk singers were invited to Livonian weddings, even though guests would not necessarily understand the songs (Salve 2011: 256, Vaalgamaa 2001: 126). As a result of extensive and prolonged contacts between the Livonian minority and Latvian majority, the Livonian community was entirely bilingual after the First World War (Ernštreits, Kḷava 2014: 78).

\section{Social network analysis}

The theoretical background on which my study is based is the model of social network analysis (SNA). Social networks were first conceptualised in sociolinguistics by the influential Belfast study led by Milroy (1987). In her study, the concept is regarded as "a set of procedures rather than a fully-fledged theory" (ibid.: 46), but the lack of a theory in social network analysis was already pointed out by Barnes (1972: 2-3; also cf. Milroy 2002: 549-550). The implication of this statement is that SNA is used in this study bearing in mind that the parameters of the Livonian social network should be treated more as general indications rather than evidence of actual language use (also cf. Bergs 2005: 23-24). 
The term 'social network' means that an individual's social network is a sum of relationships with other individuals, whose informal social mechanisms also support language varieties specific to social groups (Milroy 2002: 549). The quality of the relations between individuals in the network are judged as either 'stronger' or 'weaker' based on the density and multiplexity of connections between the individuals. Density is measured by dividing the number of all existing links between individuals by the number of potential links between the same individuals. The higher the resulting number, the denser the network is (Milroy 1987: 50).

Multiplexity indicates the content of contacts between individuals: if individuals are connected in one function or role, their link is uniplex, whereas different functions or roles for interaction between individuals makes the link multiplex (f.ex. individuals are not only neighbours, but also relatives, workmates, etc.). Multiplexity is counted by dividing the number of multiplex ties of an individual by the number of actual ties (ibid.: 51). Social networks can be used to determine the social group's resistance to language change by examining the density and multiplexity of networks: dense and multiplex networks indicate the enforcement of network norms and maintenance of vernacular forms, whereas loose and uniplex networks indicate vulnerability to external influence (Milroy 2002: 564-565; Milroy 1987: 50, 181-183; Bergs 2005: 33).

In such a model, linguistic innovations are spread by individuals in the periphery of social networks, called innovators. These individuals, being in the periphery of one social network, can be connected to another network and act as a bridge between the two networks. Since the innovators are not as densely connected to the centre of their network, they do not have as large a social obligation to follow social norms. This enables the spread of linguistic features and even languages from one community to the other (Milroy \& Milroy 1985: 347-348).

By examining the spread of linguistic innovations through a community, the model provides a theoretical explanation for observing language change in the community. However, the social network in itself has been criticised as being inadequate in explaining the linguistic variability of a community. Other factors more central in traditional sociolinguistics, such as age and gender have been noted to be important in more recent studies as well, and the social network has been suggested to be best used in connection to other social variables (cf. Mets 2010: 31-32).

The method used in this study is the Network Strength Scale (NSS) developed by Milroy (1987), which consists of five conditions that 
each give an informant a point when a condition is met, resulting in a five-point scale of which one measures density and four measure multiplexity (Milroy 1987: 139, 141-142). The importance of the NSS is that it provides a solution to compiling sociological data. Instead of having to work separately on analysing on both a linguistic and a sociological level, sociological structures could be expressed by five criteria (Bergs 2005: 22-37).

\section{Materials and methodology}

\subsection{Social parameters}

The social data for this study were collected from ethnographic literature on the Livonians such as place and date of birth, familial relations, and linguistic situation from ethnographic descriptions of Livonian speakers. I used the gathered ethnographic information to determine the relationship of Livonian speakers with one another, which I used to create a social network map of the Livonian linguistic communities. The main sources used to gather the ethnographic data were Blumberga's studies $(2011 ; 2006)$. The studies use material gathered in the 1920s and 1930s by both the Livonian Union and Edgar Vaalgamaa, a Livonian student of theology at the University of Helsinki as well as information from the Latvian census of 1935. These sources have been analysed by Mežs (2000) and also Blumberga uses this study as one basis for her studies. In addition, Blumberga (2006) published the results of Vaalgamaa's questionnaire in her study for the first time in public.

As this study deals with a historical community, there are fewer factors available to draw conclusions upon than in a contemporary sociolinguistic study (as implied in section 3.1.). Therefore, parameters used for this study are not direct indicators of language use, but rather serve as references, based on the reported circumstance of the general linguistic and social situation on the Livonian Coast. Thus, unless direct information of language use was provided, individual language use was deduced from the general information of the Livonians.

For the social network I used a modification of the five-point Network Strength Scale (NSS) developed by Milroy (1987: 141-142). As the model of the NSS is universally applicable, but not the original NSS itself (Bergs 2005: 33), relevant parameters for the Livonian case were needed to be selected. 
The parameters were taken from the questionnaire done by Edgar Vaalgamaa between 1935 and 1937 to determine the general situation of the Livonians. The questionnaire was done for every Livonian village, with people listed according to families. The reported information included the name, age, ethnicities of both parents, fluency in Livonian, and religious denomination (Blumberga 2006: 301-352). Although there were 944 registered Livonians according to the 1935 census, Vaalgamaa's questionnaire included 1205 Livonians (Blumberga 2011: 137-139). I used as relevant parameters: the ethnicities of parents; fluency in Livonian; and religious denomination.

The ethnicity of parents indicates a tendency to uphold the Livonian language, since if both parents are Livonians, it would be expected that the home language is Livonian. The connection between language and ethnicity in this instance is established, because ethnicity is reported by the people themselves and not based on an official classification, indicating an ethnic awareness of being Livonian.

The question of ethnic awareness of being Livonian by itself does not, however, necessarily indicate fluency in the Livonian language. Of the 1205 reported Livonians in Vaalgamaa's questionnaire, 313 (26\%) didn't consider themselves Livonians. Of the remaining 892 (a figure matching the 1935 census), only $68 \%$ knew Livonian with varying fluency (Blumberga 2011: 138). This is why the second parameter of fluency in Livonian was required. Again, this was reported by the people themselves, and the level of fluency is generally indicated as: 'fluent', 'slightly fluent', 'not fluent'. I categorised 'slightly fluent' and 'not fluent' together, assuming that someone slightly fluent in Livonian would mostly use Latvian on a daily basis and therefore would be highly unlikely to pass Livonian on to one's own children.

The parameter of religious denomination was selected for the purpose of determining the inner social structure of the villagers. Most of the Livonians were Lutheran, but in the second half of the 19th century some Livonians converted to the Russian Orthodox faith, one motivation being the widespread contemporary rumour of tax reliefs if one converted to the Orthodox Church (Salve 2007: 229, 240). An Orthodox church was founded in Kūolka, $26 \mathrm{~km}$ from Sīkrõg and $9 \mathrm{~km}$ from Vaid. This church served as the meeting place for Orthodox Livonians.

Baptism, on the other hand, spread to the Livonian Coast in the beginning of the 20th century. During this time a Baptist congregation was founded in Sîkrõg. Baptist congregations valued the use of the Livonian language, which is evident from the creation and use of Livonian hymns (Salve 2007: 229, 240). Thus, religious denomination shows 
not only with whom the Livonians interacted in a common public place (as the weekly gathering of Sunday service provided a meeting point for people), but also who was more inclined to use Livonian.

\subsection{Villages and speakers}

The villages in this study are Vaid and Sīkrõg.

Vaid had a strong unilingually Livonian culture (Vääri 2016: 119). The last native speakers of Livonian hailed from the Berthold family of Zūonkõ house. This family was an important source of Livonian folklore, and academic fieldwork often focused on the Berthold family and their repertoire of folk songs and stories. The Bertholds were also conservative about their culture, which is evident in their attitude towards the spread of Baptism in Livonian villages, a process they deemed unfortunate from the point of view of preserving the Livonian culture (Vääri 2016: 111-112).

Also, Vaid was one of the last villages to become bilingual and it was in Vaid where the last Livonian children were unilingual in Livonian when starting school at the age of 8 (Vääri 2016: 138; State Education Development Agency 2007: 2). This social setting is why a prediction in this study is that the social network of Vaid is dense and that speakers from Vaid use fewer Latvian elements in their Livonian than speakers from Sikrõg. The speakers from Vaid are both from the Berthold family: Pētõr Berthold (born in 1879) (Mägiste 1964: 53) and Aṇdrõks Zēberg (born in 1910) (Mägiste 2006: 78). Of these, Pētõr Berthold represents the older and Andrõks Zèberg the younger generation.

Sīkrõg is one the oldest Livonian villages, being first mentioned in the year 1387. In the 17th century the village functioned as a small port in northern Courland with warehouses and an hotel for seamen. The port lost importance in the 18th century due to the financial decline of the Duchy of Courland, but in the 19th century local fishermen created small fisheries to process fish intended for export. Sìkrõg was one of the largest Livonian villages and even in Soviet times when fishing on the coast was restricted, Sīkrõg was one of the few places where fishing was allowed until the 1960s (Celotajs.lv 2016; Viitso, p.c.). Speakers from Sīkrõg are from two families: Karl (Kōrli) Damberg (born in 1879), his daughter Vilma Damberg (born in 1911), and Oskar Tserbah (born in 1884). Karl Damberg and Oskar Tserbah represent the older and Vilma Damberg the younger generation. 


\subsection{Linguistic variables and materials}

Four linguistic variables were chosen for analysis: the conjunctions 'and' and 'but'; use of prepositions; use of Latvian prefixes; use of Latvian loanwords.

The sentential conjunction 'and' is $j a$ in Livonian and 'but' is $a g \bar{a}$. However, the Latvian equivalents ( $u n$ and bet, respectively) were also used in the beginning of the 20th century (Ernštreits 2013: 30).

The Latvian preposition $p a$ 'about; for' has been borrowed as $p a$ into Livonian. This functionally compares to the Livonian translative function (the state of becoming something) of the instrumental case and in Livonian the construction with the preposition is used to distinguish the use of the translative function from the comitative function (Ernštreits, Kḷava 2014: 82).

Latvian uses prefixes to create a perfective aspect in the imperfect tense as opposed to the imperfective aspect, for example: es lasiju 'I was reading' vs. es izlasiju 'I read' (Hewson, Bubenik 1997: 142). Latvian prefixes were fully acquired into Livonian, for example: $s a$ - (samūoštab 'understands', cf. Latvian saprot 'ibid.') or ie- (iegrumānikäd 'enemies', cf. Latvian ienaidnieki 'ibid.'), although they were a recent development and excluded from literary Livonian in the 1930s (Ernštreits, Kļava 2014: 82).

The 1938 Livonian dictionary by Lauri Kettunen consists of 10000 lexemes that can be reduced to about 5500 headwords. About 2050 words belong to the younger loanword stratum which developed from the 14th century onwards, $37.2 \%$ of the overall lexicon. The majority of loanwords is from Latvian, 1875 words (91.4\% of loanwords). Latvian loanwords are mostly nouns $(1196,63.9 \%)$, which are semantically mainly connected to society and aspects of social life, but also to cultural influences, such as new clothing styles, luxury items and spiritual terminology. The overall semantics of Latvian loanwords point to the Livonian community as a minority within the wider Latvian community, through which general cultural influences filtered (Winkler 2014: 216-217, 221, 225-226).

The linguistic materials for Vaid were from published materials of fieldwork materials collected by Julius Mägiste (2006 \& 1964). Mägiste's materials that were published in 2006 were collected in 19471948. The texts were collected from Livonians who had fled to Sweden during the Second World War, as had also Mägiste himself (Mägiste 2006: xixii). Materials published in 1964 were collected in autumn 1943 
during an expedition to Courland (Mägiste 1964: 7). Mägiste's texts were originally written in the Uralic Phonetic Alphabet, so I transcribed them according to the modern Livonian orthographic standard to better enable counting of both words and utterances.

The linguistic materials for Sīkrõg were obtained from the Folklore Archive of the Estonian Literature Museum (hereon ERA). The materials are texts transcribed by Valts Ernštreits in 2013. The texts were transcribed from catalogued fieldwork materials collected by the Estonian folklorist Oskar Loorits between the years 1920-1924. The texts are stories written in prose and they are written slightly differently from the modern orthography rules, the most noticeable differences being that long vowels in the second syllable are not marked with a macron and that the broken tone, or stød, is not shown consistently. The materials transcribed by Ernštreits are according to the modern orthographic standard of Livonian.

\section{Procedure and results}

\subsection{Social networks}

The software for the social networks was the open-source graph visualisation platform Gephi 0.9.1 (Gephi 2016). This software has been used in network analyses to visualise, for example, the global connectivity of New York Times content (Leetaru 2011) or Twitter network traffic during social unrest (Panisson 2011).

The parameters (ethnicity, fluency in Livonian, religious denomination) were compiled in Microsoft Excel onto a spreadsheet. Individuals were arranged into rows and those with the same parameter were connected as a link, or edge in two columns, one column labelled source, the other target. The spreadsheet was then imported into Gephi and run through the Force Atlas layout. Each of the parameters was given a weight value of 1 . In addition, members of the same family were given a weight value of 2 to emphasise the nuclear families as the smallest units in the social networks.

\subsubsection{Vaid}

The village of Vaid had 106 reported inhabitants in 1935 (Vaalgamaa 2001: 161). Vaalgamaa gathered information of 60 inhabitants (Blum- 
berga 2006: 314-315). The social network had 60 nodes and 1077 connections out of a possible 1770 connections, giving the map a density of $60.85 \%$. The social network map for Vaid village is shown in Figure 1.

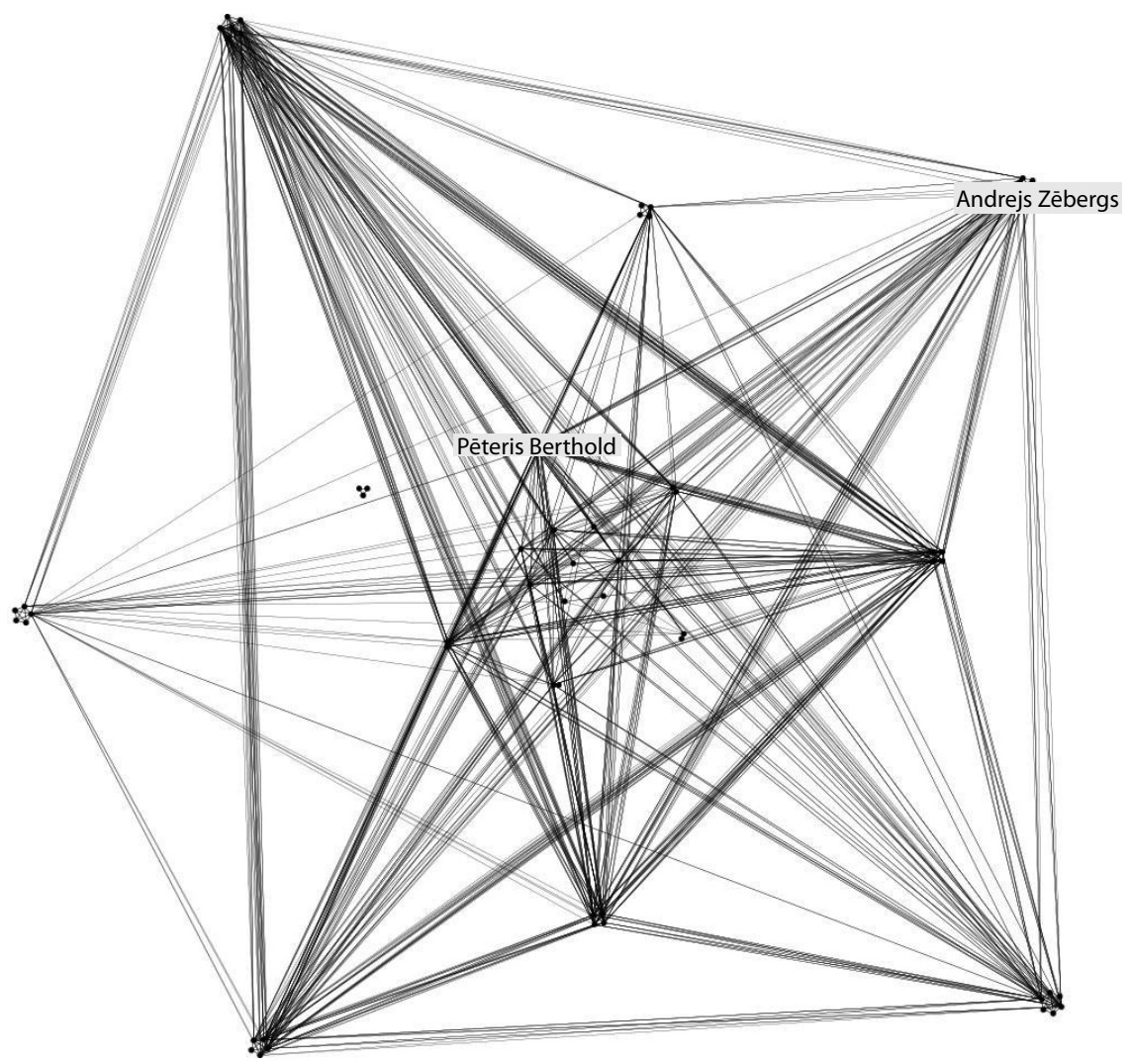

Figure 1. Social network map of Vaid village (Pētõr Berthold marked in the centre as Pēteris Berthold and Andrõks Zēberg marked in the upper right corner as Andrejs Zēbergs).

Of the 60 people, $32(53.33 \%)$ were male and $28(46.67 \%)$ were female. $20(33.33 \%)$ were at least 51 years old, $18(30 \%)$ were between the ages of 50 and 31 years, $9(15 \%)$ were between the ages of 30 and 16 years and $13(21.67 \%)$ were 15 years old or younger. This indicates that the Livonian-speaking community was very much an aging one.

A majority of 44 people was Lutheran $(73.33 \%)$. In addition, there were 14 Baptists (23.33\%), 1 Orthodox (1.67\%, in the oldest age group), and 1 Catholic (1.67\%). According to parents' reported ethnicity, 
$33(55 \%)$ were solely Livonians, 21 (35\%) had one Livonian parent, and $6(10 \%)$ were not Livonian.

Generally, those who were reported as homogeneously Livonian were also the majority of those fluent in Livonian. Overall, 27 people (45\%) were fluent in Livonian. 24 of these (72.73\%) were homogeneous Livonians, so $3(14.29 \%)$ had one Livonian parent, including the other speaker from this village, Andrõks Zēberg.

The map shows that the Livonian community of Vaid was looser than predicted. While $60.85 \%$ could still count as slightly dense, the Livonian speakers in Vaid nonetheless amount to only $25.47 \%$ of the overall amount of 106 inhabitants. The map also shows the strong presence of Livonian-Latvian families, connecting nuclear families - through the Livonian members of these families - to one another. Four families had one person who spoke Livonian, which means that the social network includes 14 people from the families who reduced the density of the network. As the size of the Livonian community in Vaid was small in general, such a demographic situation would have been detrimental to the Livonian language in the village.

Even though the Baptists were reported to value and use the Livonian language, the results do not show the Baptists standing out as a group of fluent Livonians: there were 4 Baptists fluent in Livonian (14.81\% of Livonian speakers).

Of the two speakers from Vaid, Pētõr Berthold (hereon PB) was born in 1879 so he was 56 years old when Vaalgamaa compiled the questionnaire. He was part of the Berthold family, although he and his wife Lìze were not in the same household as other members of the family. He was Livonian on both his parents' sides and Lutheran. He is connected to 26 individuals through a common language and to 32 through a common ethnicity. Twenty-three individuals are connected to him through both language and ethnicity, giving him a multiplexity percentage of $65.71 \%$. Andrõks Zēberg (hereon AZ) was born in 1909 and baptised a Lutheran. As mentioned in section 4.1., he was from the Berthold family, although his father was Latvian. Nevertheless, his home language was Livonian, marking him out as an exception to the general tendency of LivonianLatvian families switching to Latvian. Such a switch is evident in four other families in the survey, where one of the parents is Livonian ( 2 fathers and 2 mothers). As Zēberg was half-Latvian, he is connected to 26 individuals only through language. 


\subsubsection{Sīkrõg}

The village of Sīkrõg had 193 inhabitants in 1935 (Vaalgamaa 2001: 161). Vaalgamaa gathered information of 136 inhabitants (Blumberga 2006: 332-335). The social network map included 129 individuals since seven individuals did not connect to the social network, but formed groups of three individuals at most. The social network had 6907 connections from a total of 8256 potential connections, giving the network a density of $83.66 \%$. The social network map for Sīkrõg village is shown in figure 2.

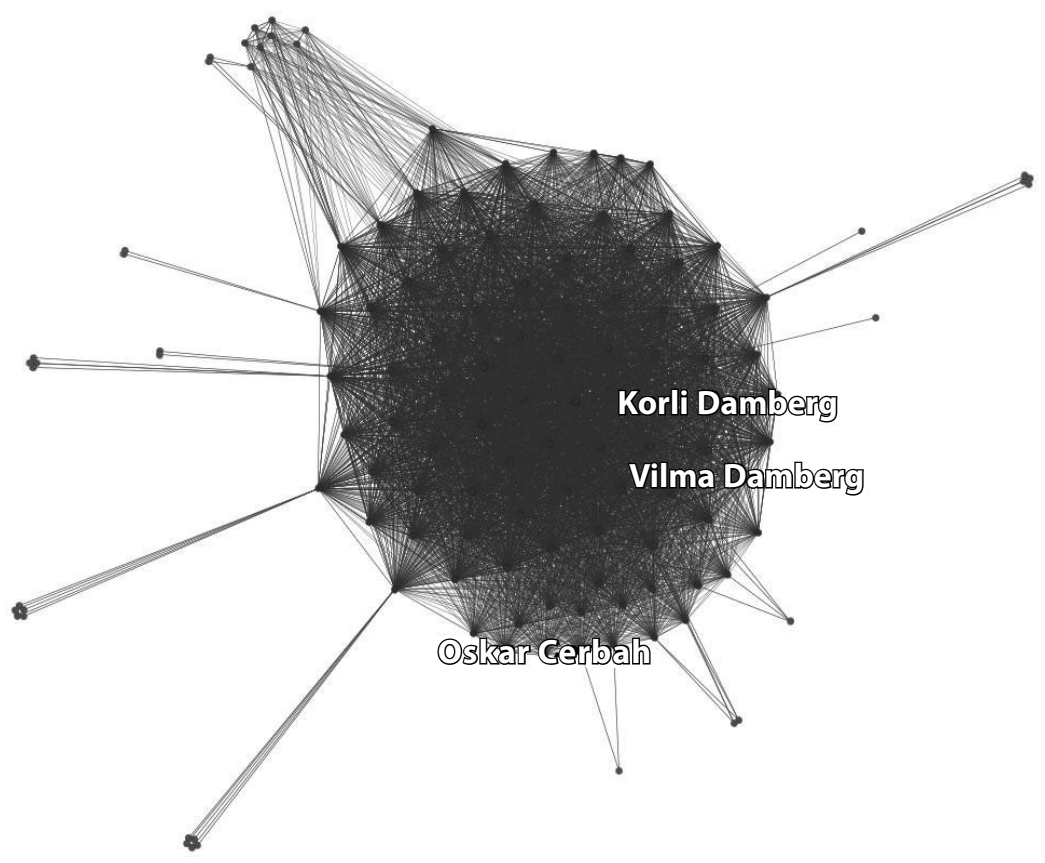

Figure 2. Social network map of Sīkrõg village (Oskar Tserbah marked at the bottom and Karl (Kōrli) and Vilma Damberg marked on the right side of the network).

The social network of the Livonian community in Sìkrõg was much denser than in Vaid. Even when the 129 people of the social network are compared to the overall amount of inhabitants (193 people), the Livonian community still amounts to $66.84 \%$ of the village inhabitants. Such a density indicates that the Livonian community in Sīkrõg had good conditions for resisting Latvianisation. 
A total of 107 people was Lutheran $(78.68 \%)$. There were also 20 Baptists (14.7\%), 2 Orthodox (1.47\%), 1 Catholic $(<1 \%)$, and 7 religiously undefined people (5.15\%). Over half of the Baptists were fluent in Livonian (11 individuals, 55\%).

Overall there were 87 people fluent in Livonian. Of these, 71 $(81.61 \%)$ were homogeneous Livonians. As in Vaid, also in Sīkrõg the Livonian-speaking population was aging, since $68(78.16 \%)$ speakers were at least 31 years old. Also, the amount of Livonian-Latvian families shows strong Latvianisation: out of 11 families with one Livonian parent, Livonian was spoken in two of them. In three of the families the mother was Livonian. Since Livonian men were predominantly fishers, the linguistic competence within the Livonian-Latvian families could indicate that there was a tendency for the mother tongue to be a defining factor in determining the child's language skills.

An ethnic difference between Vaid and Sīkrõg was the high amount of people other than homogeneous Livonians who spoke Livonian. There were 10 Livonian speakers whose other parent was not Livonian or homogeneously Livonian, 3 of whom had one Estonian parent. In addition, there was one Estonian and a Latvian family of five who were fluent in Livonian. This reinforces the interpretation of the Livonian community having good conditions for resisting Latvianisation, as even some non-Livonians were Livonianised.

Karl Damberg (hereon KD) and Vilma Damberg (hereon VD) were both Lutherans, living in a large household of 7 people, five of whom were of the Damberg family. Both had 72 connections with other individuals through common ethnicity (two ethnic Livonians did not speak Livonian) and 86 connections through language, giving each a multiplexity percentage of $79.55 \%$.

Oskar Tserbah's (hereon OC) father was Latvian, yet he did speak Livonian. One reason for this might be that his wife, Miina Tserbah, was an Estonian who had come to work in Sīkrõg in the local fishery at the beginning of the century. This would reinforce the suggestion in section 2.1. that the Estonian community helped the Livonians in preserving their own language. It is also through language that $\mathrm{OC}$ had 86 connections with other individuals in the network, making his connections uniplex. 


\subsection{Latvian influence in Livonian}

For the linguistic analysis, I measured the amount of Latvian influence by using frequency counts from texts. This is the most straightforward method to working with quantitative data, in which the number of items (or tokens) within a text that belong to a specific category (or type) are arithmetically counted (McEnery, Wilson 1996: 67). The results of the token counts are presented in sections 5.2.1. to 5.2.4. below.

The amount of words and utterances of the speakers ranged from 191 words and 18 utterances (OC) to 653 words and 61 utterances (AZ). The total amount of data was 2083 words and 196 utterances and the average amount was 416.6 words and 39.2 utterances. The amount of words and utterances of the speakers is presented below in table 1 .

Table 1. Amount of words and utterances used in this study.

\begin{tabular}{l|c|c} 
Informant & Words & Utterances \\
\hline PB (Vaid) & 402 & 46 \\
\hline AZ (Vaid) & 653 & 61 \\
\hline KD (Sīkrõg) & 349 & 24 \\
\hline VD (Sīkrõg) & 488 & 47 \\
\hline OC (Sīkrõg) & 191 & 18 \\
\hline Total & 2083 & 196 \\
\hline Mean & 416.6 & 39.2
\end{tabular}

\subsubsection{Sentential conjunctions}

Only one of the speakers used the sentential conjunction $j a$ 'and': PB $(4 / 6,66.66 \%)$. All other speakers used the Latvian conjunction $u n$ in their language samples (AZ: 15 tokens, KD: 20 tokens, VD: 38 tokens, OC: 7 tokens). The use of $j a$ can be seen in example 1 .

(1) Ni ne àtõ lǟnõd mólmõd sūrriek now 3PL be.3PL go.PTCP both high.way a'igõ ja vódlõnõd $k u$ tulūb miez. edge.ILL and wait.PTCP that come.3SG man

"Now they both went by the highway and waited for a man to come." Pētõr Berthold (Mägiste 1964: 54). 
The use of contrastive conjunctions, on the other hand, shows greater variation. Of the speakers, only $\mathrm{OC}$ had no instances of either the Livonian ag $\bar{a}$ 'but' or Latvian bet 'but'. KD and VD had instances of both forms: KD had two Livonian forms out of five tokens (40\%) and VD had one instance of both the Livonian and Latvian forms. Within the Berthold family, PB had only Livonian forms (2 tokens) and AZ had only Latvian forms (4 tokens). The use of contrastive conjunctions can be seen in chart 1 .

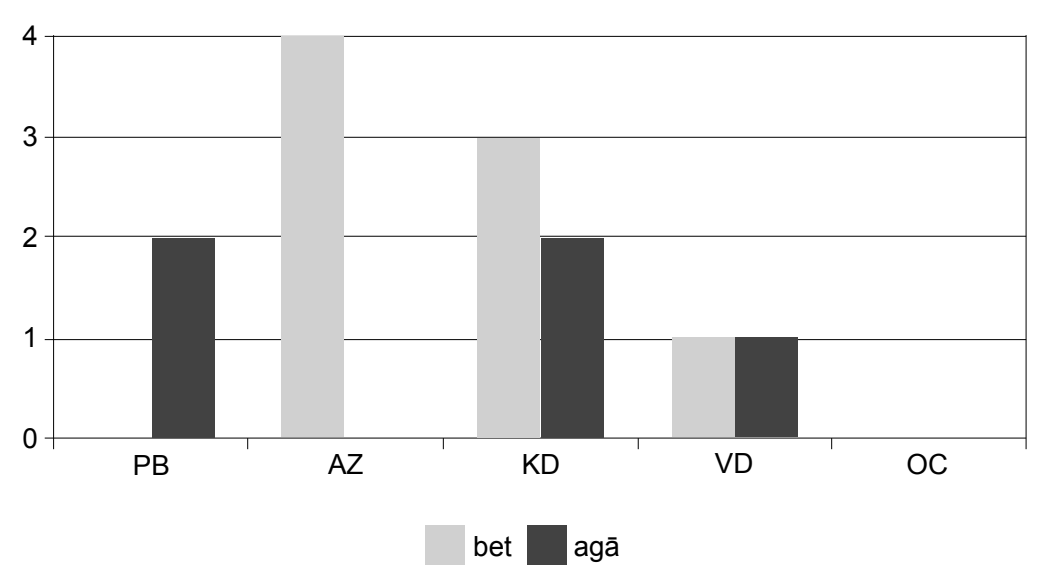

Chart 1. Use of contrastive conjunctions.

The use of the conjunctions would indicate that the use of the sentential conjunction $j a$ had already greatly receded from spoken Livonian, whereas use of the contrastive conjunction ag $\bar{a}$ still shows a more widespread distribution of the Livonian form, although use of this conjunction was apparently also receding.

\subsubsection{Prepositions}

Two of the speakers used no prepositions in the language samples: $\mathrm{PB}$ and KD. OC had only one instance of a preposition, the preposition bäs 'without', which is accommodated from Latvian (cf. Latvian bez 'id.'). The Livonian equivalent would be ilmõ 'id.' (Ernštreits 2013: 30). The use is shown in example 2. 
(2) Tallõ radl̦ond säl pūdõ un ne rọgõod winter.LOC limb.PTCP there tree.PTV and 3PL branch.PL

at vonnõd büs kitāmt-at lä 'nõd be.3PL be.PTCP without heat.PTCP be.3PL go.PTCP

kitām nēdi. heat.SUP 3PL.PTV

"[He] had limbed a tree there and the branches were without burning (=they hadn't been burnt) - they had gone to burn them." Oskar Tserbah (1884). ERA LF IV 5. Sr 77.

$\mathrm{AZ}$ also uses the same preposition, but he uses the direct Latvian form, as shown in example 3.

$\begin{array}{lllll}\text { (3) Bet si'z tu'l } & \text { täm } & \text { igā } & \text { tutkām } & \text { un } \\ \text { but then } & \text { come.PST.3SG } & \text { 3SG.GEN time.GEN end and } \\ \text { aigarōntõd } & \text { eitõ } & \boldsymbol{b e z} & \text { drukõmõt. } & \\ \text { chronicle.PL stay.PST.3PL } & \text { without publish.PTCP }\end{array}$

"But then his time came to an end and the chronicles stayed unpublished." Andrõks Zēberg (Mägiste 2006: 82).

VD has two instances of a preposition and AZ uses prepositions the most frequently ( 7 tokens). AZ's remaining instances and both of VD's instances are the preposition $p a$ 'about; for'. As explained in section 4.2., the preposition distinguishes the translative function from the comitative function in the instrumental case. However, use of the preposition is not restricted to the the translative function and/or to the instrumental case, as example 8 below shows.

AZ has 22 instances of the instrumental case, divided into 11 instances of both of the functions. Of the 11 instances of the translative function, the function is expressed with only the instrumental case ending in 6 instances and in one instance the function is expressed without the case ending, i.e., in the nominative case with only the preposition $p a$. This loss of uniformity in the case system is evident of intensive code switching. The case of the translative without the case ending is shown in example 4. 
(4) Ne munt ro'uzt àt siedā kītõn muntõn 3PL other.PL people.PL be.3PL it.PTVtell.PTCP other.PL.DAT ne nei u'm irgõn sie kilā nuttõ 3PL so be.3SG begin.PTCP it.GEN village call.INF

pa Kūolka un nei nutāb paldīn pa Kūolkaks. PREP Kūolka and so call.3SG now PREP Kūolka.INS

"The other people had told it to the others and so they had begun to call the village Kūolka and so it's called Kūolka nowadays.” Andrõks Zēberg (Mägiste 2006: 79).

The variation of the translative function without and with the preposition is shown in examples 5 and 6.

(5) Siz ta um iend pareiznikāks. then 3SG be.3SG stay.PTCP Orthodox.INS

"Then he became an Orthodox believer." Andrõks Zēberg (Mägiste 2006: 81).

(6) $T a$ vo'l Didrīk, bet $k u$ ta ei

3SG be.PST.3SG Didrik but when 3SG stay.PST.3SG

pa pareiznikāks, siz täm ni'm sai

PREP Orthodox.INS then 3SG.GEN nameget.PST.3SG

pōrkēratõd pa Dimitrieks.

rewrite.PTCP PREP Dimitri.INS

"He was Didrik, but when he became an Orthodox believer, then his name was rewritten as Dimitri.” Andrõks Zēberg (Mägiste 2006: 81-82).

A similar development is apparent from VD's use of the preposition. She uses the instrumental case in six instances, five of which are in the comitative function. The one instance of the translative function is with the preposition $p a$ and instrumental case ending. The other instance is with the nominative case and the preposition marking a translative function, as shown in example 7.

(7) Un si'z ne àtõ ki’zzõnd, mis se vóllıi and then 3PL be.3PL ask.PTCP what it be.QOUT.3SG

pa amāt.

PREP profession.

"And then they had asked what was his profession." Vilma Damberg (1911). ERA LF IV 5. Sr 66. 
In addition, the preposition $p a$ is used once by $\mathrm{AZ}$ as a conversational particle, possibly in a function resembling the use of partitive case, which is used as a case of the object. In example 8, the use of the preposition in the function of 'about' would connect it to the word for 'money'.

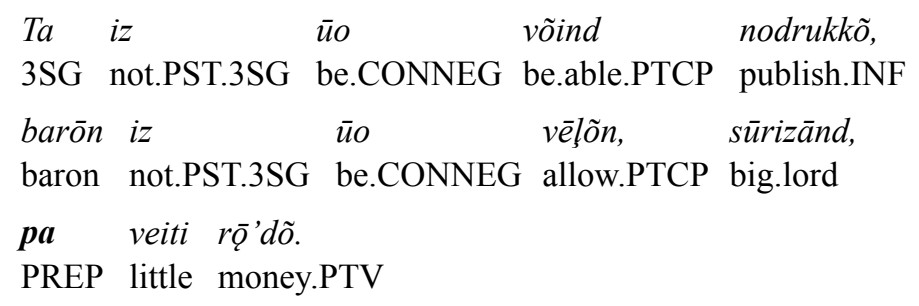

"He couldn't publish, the baron, the manor lord, hadn't allowed a little bit of money." Andrõks Zēberg (Mägiste 2006: 81).

This shows that the use of the preposition $p a$ was being used not only in a translative function, but also that it was beginning to be used in other nominal functions as well.

Examples 4 and 7 show that the increasing use of the preposition to indicate a translative function of the instrumental case was accompanied by a tendency to omit the instrumental case ending in the Livonian of the younger generation. This would probably have been due to a preference to differentiate the two functions of the instrumental case explicitly. The use of the Latvian preposition for this would indicate such a structural change in the speakers' Livonian that the Matrix language would no longer be clearly Livonian.

\subsubsection{Prefixes}

Although all of the speakers used Latvian prefixes, this variable shows a clear generational difference: both OC (24 tokens) and KD (74 tokens) use a prefix in one instance (OC: $4.17 \%$, KD: $1.35 \%$ ) and PB uses a prefix three times out of a total of 85 tokens (3.53\%). The younger speakers $\mathrm{AZ}$ and $\mathrm{VD}$, on the other hand, use a lot of Latvian prefixes (AZ: 16 out of 138 tokens (11.59\%), VD: 8 out of 83 tokens $(9.64 \%))$. Also, even among the younger generation with the heavier use of prefixes, forms without the prefix coexist even in the same sentence, as shown in example 9. 
(9) Si'z ne ātõ vödlõnd sūr āiga un ä'b then 3PL be.3PL wait.PTCP big time and not ūotõ savidlõnd tända[...] be.CONNEG.3PL wait.PTCP 3SG.PTV

"Then they waited for a long time and didn't wait for him [...]" Vilma Damberg (1911). ERA LF IV 5. Sr 67.

The introduction of the Latvian prefixes might have been influenced by the topic, as can be seen from example 10 .
Pareiznikādõn vond sūrd ti'esībõd
Orthodox.PL.DAT be.PTCP great.PL right.PL

krūonõst, siepierāst ta um ìend pa

crown.ELA because.of.that 3SG be.3SG stay.PTCP PREP

pareiznikāks, mõtlõn ku si'z ta sōb

orthodox.INS think.PTCP that then $3 \mathrm{SG}$ get.3SG

eņtš āigarōntõd izāndam, izdrukkõm, nuodrukkõm.

own annal.PL publish.SUP print.SUP print.SUP

"Orthodox people had great privileges from the crown, that is why he became an Orthodox believer, thinking that then he can have his annals published, printed.” Andrõks Zēberg (Mägiste 2006: 82).

All the instances in example 10 show concepts which are fairly recent in Livonian society, that is, from print technology. Therefore, the use of Latvian prefixes in this context can be expected, since the concepts were introduced during cultural change among the Livonians. These three instances support this assumption, since all three concepts are semantically close, which shows that the concept of publishing and/ or printing had no stabilised lexeme in Livonian. In fact, only nodrukkõ 'to print' has a direct parallel in Latvian (nodrukāt 'id.'), whereas the other two verbs (izdrukkõ, izandõ) seem to be formed based on analogy.

Nonetheless, Latvian prefixes are used also with Livonian verb stems, as example 11 shows.

(11) Se suodāmīez um ievaņ̧⿻上丨on, $k u$ louv um riek päl.

it war.man be.3SG look.PTCP that lion be.3SG road on.ADE

"The soldier saw that there was a lion on the road." Pētõr Berthold (Mägiste 1964: 54). 
Such instances show that even though Latvian prefixes originated probably from recent cultural innovations, the fact that they are used with common and everyday Livonian verbs indicates a high degree of Latvian influence.

The amount of prefixes used by the speakers is shown in chart 2 .

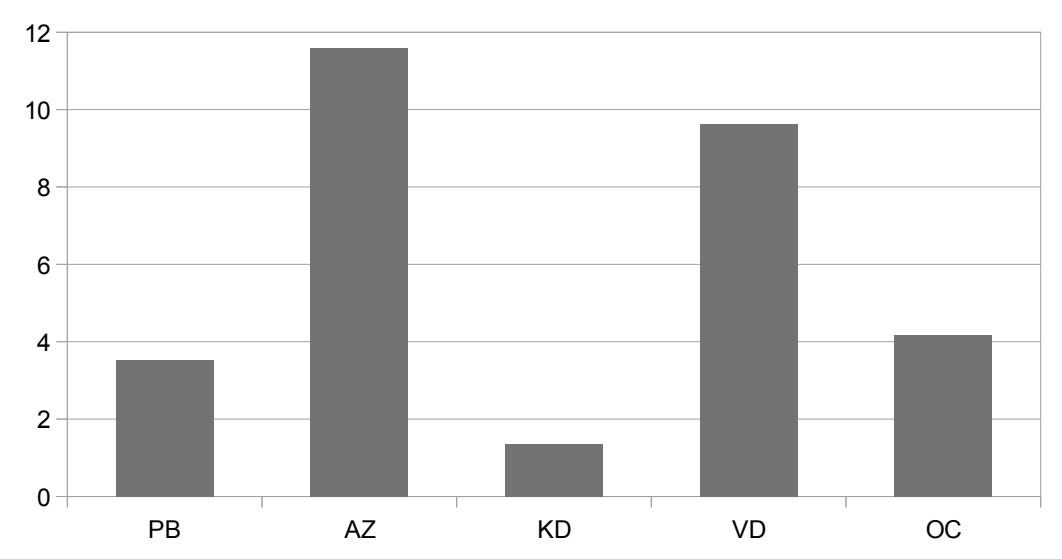

Chart 2. Percentage of prefixes by speaker.

\subsubsection{Loanwords}

Out of all the content words in the language samples, PB uses no recent Latvian loanwords, that is, Latvian loanwords for which there is a known Livonian equivalent. In fact, his language would appear to be quite archaic, judging from the use of the word suodàmiez 'soldier' in example 11 above. The corresponding loanwords would be zoldat, which is what $\mathrm{AZ}$ uses twice.

AZ has 9 instances of 6 loanwords. Besides the word for 'soldier' mentioned above, there are two instance of skuţk 'young woman, girl' from Latvian skukis 'girl, lass' (Livonian: neitst), two instances of the verb vēlo 'to allow' from Latvian novēlèt 'to wish' (Livonian: laskõ), one instance of brīv 'free' from Latvian brīvs 'free' (Livonian: vabām), and one instance of ti'esībõd 'right (plural)' from Latvian tiesības 'right (plural)' (Livonian: õigiz). There is one instance of riktig. Also, the word barōn 'baron' is included in the recent loanwords, since as example 8 shows, a Livonian equivalent for the word was used, namely sūrizānd, a compound of sūr 'big' and izānd 'master'. AZ uses a loanword in $2.54 \%$ out of 355 tokens. 
OC has 8 instances of 6 loanwords. In a story describing the weather, he uses the word ga 'is 'air' from Latvian gaiss 'air' instead of the Livonian $\overline{\tilde{o}}$ 'g. The word sma'ggo 'heavily' is twice used when talking about rain. In Livonian, the equivalent when describing rain would be either with an adjective, sūr 'big' or ja'mdõ 'coarse', or with an adverb vizāstiz 'heavily'.

Also the word tšup $\bar{a}$ 'pile' from Latvian čupa 'pile' is used twice, in place of the Livonian equivalent $k \bar{u}$ 'j. Verbs of Latvian origin are: strī

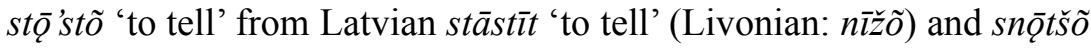
'to snort' from Latvian šņākt 'to hiss, to snort' (Livonian: pūškõ). Altogether, OC has $9.2 \%$ of loanwords (out of 87 tokens).

KD uses few loanwords (4 tokens): one instance of riktig 'right' from German richtig 'right' (Livonian equivalent: õigi), one instance of piedrõb 'threshing-floor' from Latvian piedarbs 'threshing-floor' (Livonian equivalent: $r \bar{\imath}$ '), and two instances of näjoukõz 'ugly, bad' from Latvian nejauks 'ugly' (Livonian equivalent: $\ddot{a}$ 'bjõvā). This amounts to $2.56 \%$ out of 156 tokens.

VD uses a few more loanwords, four words in five instances: once the German rikţig 'right', once the word gim 'face' from Latvian gimis 'face' (Livonian equivalent: palg), once the verb pama'ņño 'to realise' from Latvian pamanit 'to notice' (Livonian equivalent: tieudõ), and twice the verb trī'etsõ 'to drive away' from Latvian triekt 'to bang, to hit' (Livonian equivalent: $a^{\prime} j j o \tilde{)}$ ). This is $2.27 \%$ out 220 tokens.

The instances of Latvian loanwords among the speakers is shown in chart 3.

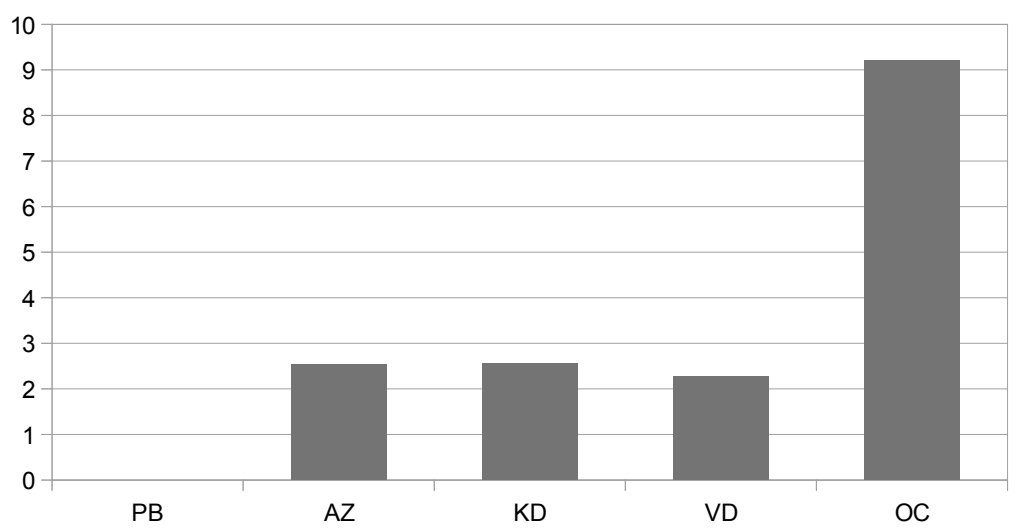

Chart 3. Percentage of loanwords by speaker. 
In general, the loanwords indicate not only the role of the Latvian community as a filter of cultural innovations for the Livonians (as pointed out in section 4.2.), but also that everyday concepts such as weather-related topics and related to social interaction were expressed using Latvian lexemes.

\section{Conclusion}

The villages showed large demographic differences in terms of the amount of Livonians. In this context it is surprising that in Vaid the older generation's Livonian was so little influenced by Latvian, considering the social context explained in section 2 . This indicates that in the youth of the older generation, the social context in Vaid was beneficial for the preservation of Livonian.

In contrast, the density of the social network in Sikkrõg would suggest that Livonian spoken there would have been less influenced by Latvian, especially since the Livonian community formed the majority in the village. Nonetheless, Livonian spoken in Sīkrõg also showed Latvian influences. A likely explanation for this would be the presence of mixed families, which contributed to Latvian becoming a language used in everyday contexts and not just in interactions with the outside world.

Returning to my research questions proposed in section 1 , the results show that Livonian-Latvian bilingualism was in fact widespread among Livonians during the interwar period. This can be seen from the structural features that can be traced to a Latvian origin, in particular the use of Latvian phrases, prepositions, and prefixes.

There were also differences in the degree of Latvian influence: for the older generation the Latvian influence was mostly lexical, whereas for the younger generation structural influence is also apparent. The use of the preposition $p a$ with the translative meaning was shown to be increasing generationally. By the time the younger generation under study had learned Livonian, the preposition had started to replace the instrumental case ending in Livonian constructions. This transition would point to the incremented use of the prepositional phrases, which would point to increased use of Latvian structure and language attrition in Livonian.

Such structural influences would confirm my first hypothesis that the Livonian speech community was already in the process of language shift to Latvian during the interwar period. 
My second research hypothesis was that speakers more central in Livonian social networks have less Latvian influences in the language. However, the results show that although those with uniplex ties had Latvian influences, the degree of Latvian influence was different for the older and younger generation. Therefore, the degree of Latvian influence was not based on centrality, but generation.

When looking at social factors affecting the Livonian community, there are different reasons interacting. Firstly, the language spoken at home determined the amount of Latvian influence in the speakers' Livonian, that is, whether only Livonian was spoken at home or whether Latvian was also spoken. Even though Vaalgamaa's questionnaire did not differentiate between the qualities of Livonian among speakers, the results indicate that those from one Livonian parent had a tendency to have more Latvian influences in their language. This would mean that even though the Livonian community was fully bilingual after the First World War, Latvian influence seems to have been accommodated through those who were bilingual at home.

A reason explaining the generational differences in the speakers' Livonian would be that the social context was more stable for the older generation, enabling the preservation of linguistic norms along with social norms. For the younger generation, the experience of living in a Latvian environment during the First World War apparently had profound consequences on Livonian language acquisition, resulting in a variety with heavy Latvian influence.

\title{
Acknowledgements
}

This article is based on my master's thesis, the details of which are as follows: O'Rourke, Patrick (2016). Mapping of the Livonian Social Network. Master's thesis, supervisor: Prof. Dunstan Brown. Department of Language and Linguistic Science, University of York; York, United Kingdom.

\author{
Address: \\ Patrick O'Rourke \\ Institute of Estonian and General Linguistics \\ University of Tartu \\ Jakobi 2 \\ 51014 Tartu, Estonia \\ E-mail: patrick.o-rourke@ut.ee
}




\begin{abstract}
Abbreviations
ADE adessive case, CONNEG connegative, DAT dative case, ELA elative case, GEN genitive case, ILL illative case, INF infinitiive, INS instrumental case, LOC locative case, PL plural, PREP preposition, PST past, PTCP participle, PTV partitive case, QUOT quotative, SUP supine, 3PL third person plural, 3SG third person singular;

AZ Andrõks Zēberg, KD Karl (Kōrli) Damberg, OC Oskar Tserbah, PB Pētõr Berthold, VD Vilma Damberg
\end{abstract}

\title{
References
}

Barnes, James (1972) "Social networks". Module of Anthropology 26, 1-29.

Bergs, Alexander (2005) Social networks and historical sociolinguistics: studies in morphosyntactic variation in the Paston Letters (1421-1503). (Topics in English Linguistics, 51.) Berlin; New York: Mouton de Gruyter.

Blumberga, Renāte (2011) “Liivlased 19.-21. sajandil”. In R. Blumberga, T. Mäkeläinen, and K. Pajusalu, eds. Liivlased. Ajalugu, keel, kultuur, 127-154. Tallinn: Eesti Keele Sihtasutus.

Blumberga, Renāte (2006) Lībieši: dokumentos un vēstulēs. Somijas zinātnieku ekspedīcijas pie lībiešiem. Rīga: LU Latvijas vēstures instituts.

Celotajs.lv (2016) Sikrags. Available online at $<$ http://www.celotajs.lv/en/e/sikrags $>$. Accessed on 13.10.2018.

Ernštreits, Valts (2013) Liivi kirjakeel. Tartu: Tartu Ülikooli Kirjastus.

Ernštreits, Valts and Gunta Kḷava (2014) "Grammatical contacts between Livonian and Latvian”. Journal of Estonian and Finno-Ugric Linguistics (ESUKA - JEFUL) 5, 1, 77-90.

Gephi (2016) Available online at $<$ https://gephi.org/>. Accessed on 13.10.2018.

Grünthal, Riho (2011) "Liivi keel uue aja esimestel sajanditel”. In R. Blumberga, T. Mäkeläinen, and K. Pajusalu, eds. Liivlased. Ajalugu, keel, kultuur, 195-202. Tallinn: Eesti Keele Sihtasutus.

Hewson, John and Vit Bubenik (1997) Tense and aspect in Indo-European languages: theory, typology, diachrony. (Current Issues in Linguistic Theory, 145.) Amsterdam and Philadelphia: John Benjamins Publishing Company.

Leetaru, Kalev H. (2011) "Culturomics 2.0: Forecasting large-scale human behavior using global news media tone in time and space”. First Monday 16, 9. Available online at <http://journals.uic.edu/ojs/index.php/fm/article/view/3663/3040>. Accessed on 13.10.2018.

Mets, Mari (2010) Suhtlusvõrgustikud reaalajas: võru kõnekeele varieerumine kahes Võrumaa külas. (Dissertationes philologiae estonicae Universitatis Tartuensis, 25.) Tartu: Tartu Ülikooli Kirjastus. Available online at $<$ http://dspace.ut.ee/handle/10062/14781>. Accessed on 13.10.2018. 
Mežs, Ilmārs (2000) "Kurzemes lībiešu ciemu iedzīvotāji pēc 1935. gada tautas skaitī̌sanas uzskaites lapām”. Latvijas Zinātņu Akadēmijas Vēstis. A dala. 3-4, $56-62$.

McEnery, Tony and Andrew Wilson (1996) Corpus linguistics. (Edinburgh Textbooks in Empirical Linguistics.) Edinburgh: Edinburgh University Press.

Milroy, Lesley (1987) Language and social networks. 2nd ed. Oxford and New York: Basil Blackwell.

Milroy, Lesley (2002) “Social networks". In J. K. Chambers, Peter Trudgill, and Natalie Schilling-Estes, eds. The handbook of language variation and change, 549-572. Oxford and New York: Blackwell.

Milroy, Lesley and James Milroy (1985) "Linguistic change, social network and speaker innovation". Journal of Linguistics 21, 339-384.

Moseley, Christopher (2014) "Livonian - the most endangered language in Europe?" Journal of Estonian and Finno-Ugric Linguistics (ESUKA - JEFUL) 5, 1, 61-75.

Mägiste, Julius and Anneli Honko, ed. (2006) Muistoja Liivinrannasta. Liivin kieltä Ruotsista. (Suomalais-ugrilaisen Seuran Toimituksia, 250.) Helsinki: Suomalaisugrilainen Seura.

Mägiste, Julius (1964) Liiviläisiä tekstejä. (Suomalaisen Kirjallisuuden Seuran Toimituksia, 276.) Helsinki: Suomalaisen Kirjallisuuden Seura.

Panisson, André (2011). The Egyptian Revolution on Twitter. Available online at $<$ https://www.youtube.com/watch?v=2guKJfvq4uI $>$. Accessed on 13.10.2018.

Salve, Kristi (2007) "Liivi rahvausundist ja folkloorist”. In Mare Kõiva, Taive Särg, and Viire Villandi, eds. Paar sammukest: Eesti Kirjandusmuuseumi aastaraamat 13, 213-272. Tartu: EKM Teaduskirjastus.

State Education Development Agency (2007) Latvia: system of education. (State Education Development Agency of Latvia.) Riga: Ministry of Education. Available online at $<$ http://www.viaa.gov.lv/files/news/1808/educ_in_latvia.pdf $>$. Accessed on 13.10.2018.

The Red Book (1993) "The Livonians". The Red Book of the peoples of the Russian Empire. Available online at <http://www.eki.ee/books/redbook/livonians.shtml >. Accessed on 13.10.2018.

Vaalgamaa, Edgar (2001) Valkoisen hiekan kansa. Jyväskylä: Atena Kustannus Oy.

Viitso, Tiit-Rein (2008) Liivi keel ja läänemeresoome keelemaastikud. Tartu and Tallinn: Eesti Keele Sihtasutus.

Vunk, Aldur (2014) "Metsepole Livonians from the 14th to the 17th century". Journal of Estonian and Finno-Ugric Linguistics (ESUKA - JEFUL) 5, 1, 37-60.

Vääri, Eduard (2016) Liivi rahva keel ja meel. Eduard Vääri uurimused liivlastest ja liivi keelest. (Eesti Teaduste Akadeemia Emakeele Seltsi Toimetised, 74.) Tallinn: Emakeele Selts.

Winkler, Eberhard (2014) "Loanword strata in Livonian". Journal of Estonian and Finno-Ugric Linguistics (ESUKA - JEFUL) 5, 1, 215-227. 
Kokkuvõte. Patrick O'Rourke: Liivi keele sotsiaalsed võrgustikud ja keelevahetus. Artikkel tutvustab uurimust Kuramaa liivlaste sotsiaalsetest võrgustikest 20. sajandi esimesel poolel, kui keelevahetus liivi keelelt läti keelele oli juba alanud. Autor vaatleb, kuivõrd liivi kogukondades sõltus keelevahetus kahe maailmasõja aegsest elanikkonna deporteerimisest, mida on tavaliselt peetud keelevahetuse põhjuseks. Rakendatakse suhtlusvõrgustike tugevuse analüüsi, et selgitada, kas isiku keskne asend sotsiaalses võrgustikus oli keelevahetuse jaoks oluline. Uurimus keskendub liivi küladele Vaid ja Sīkrõg. Sotsiaalsete võrgustike kaardistamiseks on valitud olulised tegurid Edgar Vaalgamaa poolt aastatel 1935-1937 läbi viidud küsitluse põhjal. Tulemused näitavad, et läti keele mõju ulatus sõltub rohkem põlvkondlikest erinevustest kui isiku asendist sotsiaalses võrgustikus. Artikkel põhineb autori magistritööl, mis on kaitstud 2016. aastal Yorki Ülikoolis.

Märksõnad: ajalooline lingvistika, sotsiolingvistika, sotsiaalsed võrgustikud, keelevahetus, liivi keel

Kubbõvõttõks. Patrick O'Rourke: Līvõ kīel sotsiālizt võrgõd ja kīel vaidimi. Kēra tunš̌lõb Kurāmō līvõd sotsiāliži võrgidi 20. āigastsadā ežmizõs pūolsõ, ku vỏl irgõn līvõ kīel vaidimi lețkīelkõks. Kēratiji vaņţlõb, kui ulzõ ajjimi kōd mōilmasuodā āigal mỏjīz kīel vaidimiz līvõd kubgõņis. Sīe pierāst um kõlbātõd rovst võrgõd viššit analīz. Analīz abkõks um sel̦ţõd, või se, ku rištīngõn um vỏnd sidāmi kūož sotsiālizt võrgõd sizāl, um vỏnd ka tādzi kīel vaidimiz āigal. Tuņšlimizõs amā jemīṇ ātõ van̦țõltõd līvõd kilād Vaid ja Sīkrõg. Sotsiālizt võrgõd tātimiz pierāst um kōlbatõd Edgar Vālgamō 1935.-1937. āigast tīedõd rovkizzimi. Tuņšlimi nägțõb, ku lețkīel mỏjjimi jemīṇ um sidtõd sugkazāmõks, äbku rištīng kūožõks sotsiālizt võrgõd sizāl. Kēra alīzõks um kēratijiz magistõrtīe, mis um kaitstõd 2016. āigasts York Iḷīzskūols. 